May 11, 1994

\title{
Stigma Happens: Social Problems in the Siting of Nuclear-Waste Facilities
}

\author{
Paul Slovic, ${ }^{1,2}$ James Flynn, ${ }^{1}$ and Robin Gregory ${ }^{1}$
}

Abbreviated Title: Stigma Happens

Key Words: Perceived risk, stigma, economic impacts, nuclear waste

Acknowledgment: Work on this paper was supported by a grant from the Alfred P. Sloan Foundation. We thank James Chalmers, Doug Easterling, Howard Kunreuther, Don MacGregor, and Sarah Lichtenstein for their comments.

${ }^{1}$ Decision Research, 1201 Oak Street, Eugene, Oregon 97401.

${ }^{2}$ To whom all correspondence should be addressed. 


\section{STIGMA HAPPENS: SOCIAL PROBLEMS IN THE SITING OF NUCLEAR WASTE FACILITIES}

The paper by Metz challenges the view that stigma associated with a nuclear waste repository might lead to significant economic losses to the host region. We have been invited to comment on the general issues raised by this paper. We find that much of the evidence presented in the paper consists of factual and conceptual errors and misrepresentations of the research literature. Based on our review of evidence documenting the social and economic impacts of perceived risk, we conclude that stigma is an important phenomenon that is symptomatic of fundamental problems with the way that nuclear waste facilities are sited.

\section{CONCEPTUAL PROBLEMS}

The following are some of the more blatant conceptual problems with the paper:

- The author claims that requests for policy makers to "rethink" the congressionally mandated siting policy for centralized high-level waste storage and disposal facilities are caused by state government opposition based on surveys that predict negative economic impacts. This is incorrect. These requests for reevaluation stem primarily from the fact that the policy is not working. Critics cite unrealistic schedules, wildly escalating costs, and lack of an adequate technical and management plan. ${ }^{(1-2)}$

- The author claims that predictions of possible adverse effects are based on surveys of people's stated intentions. The major study of potential economic impacts of a nuclear waste repository ${ }^{(3)}$ did not rely on stated intentions. Indeed, it acknowledged the limitations of such intentions. Instead, it developed and tested a theoretical model of the stigmatization process. This model demonstrates how the images of a place affect its desirability as a place to visit, live, and do business. It is consistent with the image model 
that is widely recognized as the driving force behind marketing and advertising of products (e.g., automobiles, political candidates). The theory predicts that, if the imagery of Las Vegas and Nevada were to become increasingly associated with negative images of a nuclear waste repository, the attractiveness of these places would decline. The decision maker is not assumed to be aware of this effect of imagery (nor did anyone we studied ever indicate such awareness), contrary to what the author states.

- Another conceptual misrepresentation is that lack of documented evidence for adverse economic effects indicates that no such effects have taken place. Social impact assessment requires more than just casual observation of a region's economic health. It requires careful analysis of the present and projected economic state compared with alternative scenarios (e.g., what would things have been like without the reactor or the repository?).

\section{FACTUAL ERRORS AND MISREPRESENTATIONS}

Readers of the article also need to be aware that the author has distorted facts and misrepresented the existing literature in attempting to build a case for his paradoxes. For example:

1. Citing a deposition of one researcher, James Chalmers, the author claims that "researchers [plural] forecast that significant economic impacts would be felt [in Nevada] as early as October, 1991, with the grant of the state water permit...." Chalmers actually stated that he knew of no research examining the relation between a water permit and public perception. ${ }^{(4)}$ He added that "If it [the permit] becomes a proxy ... for ... the consequences of the entire project, then clearly a whole range of consequences stem from it" [emphasis added]. 
2. The author cites D.R. Wernette's unpublished statement that "When Oregon residents were confronted with a federal plan to transport HLW on a nearby interstate, only 4 out of $127(3 \%)$ respondents who lived closer than they preferred to that highway said they would very likely move over the next 5 years ..." This information appears to come from one of our surveys. ${ }^{(5)}$ The respondents were not asked whether they would move in response to the HLW transportation. They were asked (before any mention was ever made of HLW): "Thinking about the next 5 years or so, how likely is it that you will stay in this community?"

3. The author has misrepresented the study of convention attendees by Easterling and Kunreuther. ${ }^{(6)}$ He says that "people have stated they would not attend a conference if they learned that the host location was within 100 miles of a nuclear reactor, yet most major convention cities ... have one or more nuclear reactors within 100 miles ..." Actually, only about $3 \%$ of the respondents gave this response. The point made by Easterling and Kunreuther was that finding such a small percentage enhanced the credibility of the reports. Also, the fact that $23 \%$ said they would avoid a HLNW repository indicated that this facility was regarded as much more noxious than a nuclear reactor.

4. The author writes that " . . $12 \%$ of the respondents in a Phoenix sample preferred to be somewhere else ("as far away as possible") when asked about an underground nuclear waste storage facility ..." Because Phoenix is located near a nuclear reactor, he calls this response "a seeming contradiction." Actually, the respondents were not asked for their preferences; they were asked to give word associations. Moreover, the phrase "far away as possible" was an association given by one person (out of 402 surveyed) to the stimulus "underground nuclear waste storage facility." 
5. The author questions the strength of conviction (he calls it subjective certainty) of public perceptions of risk because in response to one question in one survey only one-third of the respondents said they were "very certain" regarding their beliefs about risks from nuclear and chemical wastes. This is hardly evidence of anything. There is ample evidence that people's concerns about such wastes are deeply felt. Such concerns have led the nuclear power industry to spend millions of dollars in an unsuccessful attempt to change Nevadans' perceptions about the risks from nuclear waste. ${ }^{(7)}$

6. The author claims that the link between stated intentions and actual behavior is weak. This statement misrepresents the results of hundreds of studies that have created a precise understanding of the conditions under which attitudes and intentions do and do not predict behavior well. ${ }^{(8)}$ Convention planners, for example, are one group whose intentions need to be taken seriously. ${ }^{(6)}$ There are, of course, limits to what people can expect to know about their behavior in the distant future. That is why the case for possible economic impacts has been built primarily around image theory, rather than relying on people's stated intentions.

\section{RESOLVABLE PARADOXES}

The major arguments in the paper center around presumed inconsistencies characterized as paradoxes. These paradoxes involve inconsistencies between the distance people say they would prefer to live and the distances they actually live from nuclear facilities. The author argues that people's fears and perceptions are not reflected in where they chose to live or other behaviors in the marketplace. His arguments fail on several counts. Factually, we have already noted that many of the supporting statements are incorrect. In many other instances, 
where the author says there is no evidence counter to his statements, there is simply no evidence-the studies have not been done.

In his discussion of people's stated unwillingness to live close to nuclear facilities, the author misrepresents the way in which this issue was treated in the surveys. Respondents to one survey were asked for the closest distance a plant could be built from their home before they would want to move. In another, they were asked, "please tell me the fewest number of miles you would prefer to live or work from each of the following facilities if you had a choice" [emphasis added]. These distance questions were simply used in the surveys as measures of aversiveness on which to compare several facilities (e.g., a nuclear plant, an oil refinery, a landfill, etc.).

Moreover, there is no paradox behind the fact that people's preferred distances (if they had a choice) and their actual distances are not always consistent. The requirement of consistency assumes that people are always free to express their preferences through their actions. This is not true. The fact that millions of people live in polluted, crime-infested cities with harsh climates does not mean that they prefer to live under such conditions, nor that crime, pollution, and severe weather do not harm local economies.

But even if people were free to escape their present environment, where could they go? The author notes that, because of a "nuclear omnipresence," $80 \%$ of the population of the contiguous United States reside within 100 miles of an operating nuclear reactor.

In presenting Paradox 2, the author uses responses to the Three Mile Island accident to question whether people react physically to the perception that nuclear reactor accidents can be catastrophic. He fails to note that when the Governor of Pennsylvania issued an advisory suggesting that it might be wise for pregnant women and young children to leave the area 
after the accident, 144,000 residents (39\% of the population living within 15 miles of the reactor) began a frenzied evacuation. Years later, psychologists documented evidence of abnormal stress in persons who continued to live in the area. ${ }^{(9)}$

The claim of no apparent shift in business and demographic location near DOE facilities such as Rocky Flats and Hanford may simply reflect the absence of systematic study of such regions. We do know, however, that the publisher of the local newspaper in Hanford, Washington, proposed to rename the Hanford Reservation the "Gable Mountain National Environmental Site" because, in his words, "Hanford's reputation is so poisoned in the region the mere name conjures up negative images."(10) Furthermore, the claim of no impacts is not entirely true. In 1989 , the Department of Energy agreed to pay $\$ 73$ million to neighbors of the Fernald nuclear weapons plant in Ohio to compensate them for emotional distress and diminution of property values caused by uranium contamination produced by the plant. (11)

Much is made of the fact that negative effects of a repository have not been seen in the Las Vegas economy. First, despite the issuing of the water permits, the repository in Nevada does not exist and there is a significant possibility that it will not be built at all. If it is built, it will not be completed for at least several decades. The time horizon of most investors and developers is certainly shorter than that. Second, the theory put forth to predict impacts conditions such impacts on the occurrence of key events that trigger negative images that, in turn, motivate individual, social, and institutional responses. ${ }^{(3,12)}$ The hypothetical status of the repository certainly inhibits the occurrence of such trigger events. Third, the fact that the Las Vegas economy has been growing does not demonstrate that negative impacts from the 
proposed repository have not taken place. A careful analysis, which has not been done, would be necessary to assess the presence or absence of such impacts.

\section{STIGMA HAPPENS}

The author asserts (Paradox 3) that location preferences based on negative images do not appear to be reflected in the marketplace or in demographic and economic behavior. Actually, there is plenty of evidence to show that publicity about the risks of some product, place, or technology, whether warranted or not, can lead to stigmatization and avoidance behavior resulting in significant economic losses.

Stigmatization of places is a familiar concept due to the extensive media coverage of contamination at sites such as Times Beach, Missouri, and Love Canal, New York. Petterson ${ }^{(13)}$ reported strong evidence of geographic stigmatization related to radiation exposure: After children in Goiania, Brazil, were contaminated with radioactive cesium chloride, hotels in other parts of the country refused to allow Goiania residents to register, automobiles driven out of the region were stoned, and airline pilots refused to fly with passengers from Goiania on board. Miami is trying hard to overcome its image as a dangerous place for foreign (and American) tourists. Other examples of stigmatization of places associated with toxic pollution have been documented by Edelstein. ${ }^{(14)}$

Stigmatization of products reflects negative news and images leading to loss of sales. A well-known case of product stigmatization occurred in the spring of 1989 , when millions of consumers stopped buying apples and apple products due to their fears that the chemical Alar (used as a growth regulator by apple growers) could cause cancer. Apple farmers saw the 
wholesale price of apples decline by about one-third (between 1989 and 1990) and nationwide revenues decline by over $\$ 100$ million (roughly $10 \%$ of 1989 revenues). ${ }^{(15)}$

The consequences of an adverse event do not have to be massive to trigger substantial economic impacts. The seven deaths due to the adulteration of Tylenol in 1982 resulted in more than 125,000 stories in the print media alone and inflicted losses of more than $\$ 1$ billion on the Johnson \& Johnson company, due to the damaged image of the product. ${ }^{(16)}$

The research sponsored by the State of Nevada has led to the development and partial testing of a theoretical mechanism to explain how stigmatization and resulting economic losses could occur as a result of a HLNW repository. This research has never produced specific forecasts of economic losses associated with a repository. Rather, the carefully worded conclusions have stated that negative images associated with nuclear waste "appear to have the potential to cause substantial losses to each of the various economic sectors at risk" (Ref. 3, p. 693). Because of the uncertainties regarding whether stigmatization would happen and how great the effects might be, researchers have further characterized the development of a repository at Yucca Mountain as forcing "Nevadans to gamble with their future economy. The nature of that gamble cannot be specified precisely . . " (Ref. 3, p.694).

The possibility of stigma effects has traditionally been ignored or dismissed by the DOE (see, e.g., Ref. 17). The author would have these potential impacts continue to be ignored pending the documentation of "proven negative economic effects." It is disturbing that the author excuses federal policy makers from the responsibility of addressing potential economic impacts and places the burden of proof upon those who might be the victims of such impacts. 


\section{FACING THE STIGMA PROBLEM}

The most disturbing aspect of the paper is that the author seems to be advocating tactics in a battle against "the opposition" that will lead us deeper into the abyss. Whereas many analysts of the "nuclear waste wars" have begun to call for greater respect for public views and greater public participation in the siting process, ${ }^{(18-20)}$ the author sees the public as an obstacle whose scientifically groundless concerns should be ignored. He asserts that "Various interest groups and state governments opposed to the siting of ... HLW ... facilities are using the documented existence of a widespread feeling of dread, a fear of associated stigmas, and a perception of possible catastrophic accidents associated with the nuclear fuel cycle to create a powerful, emotional obstacle to the siting." He bemoans the vehement opposition to nuclear facilities, noting that "Negative imagery exists despite the fact that a nuclear omnipresence has evolved in the United States, with over 200 nuclear-related facilities involved in the manufacture, use, research, testing, and disposal of nuclear fuel ...."

The real problem is right under the author's nose, and he misses it. If citizens have such "documented fears" of the "nuclear omnipresence" that has engulfed them, is it not proper for public interest groups and state governments to represent their cause? What evidence is there to believe that state governments are using public fears to create emotional obstacles?

The author calls for a "robust research agenda" to resolve his paradoxes. However, the problem of assessing the social and economic impacts of a HLW repository that will not exist for decades, when those impacts will be triggered by accidents and other management problems that are themselves difficult to forecast, may be beyond the capacity to be resolved by present-day research. As long as the various parties are at war with each other, there will 
be no agreement about the magnitude of the stigma problem. The economic gamble will remain unspecified.

We know enough already to see that stigma is but a symptom of a more fundamental problem. The key to dealing with the nation's high-level nuclear waste problem lies not in pinpointing the magnitude of stigma effects but in reforming the siting process (see, e.g., Refs. $18-20$ ). It is wrong to attempt to locate either a temporary or permanent facility without the support of the host community and state. Congress should mandate that no community be forced to accept a repository against its will and should establish a broadbased participatory process as a means of developing public trust. Within a proper process, a plan to insure voluntary host communities against losses from stigma effects may well be negotiable. ${ }^{(21)}$ However, as long as public perceptions of risk from nuclear waste and fears of stigma effects are viewed as irrational obstacles to progress, attempts to solve the HLW problem are destined to fail.

\section{REFERENCES}

1. U.S. General Accounting Office, Nuclear Waste: Yucca Mountain Project Behind Schedule and Forcing Major Scientific Uncertainties (GAO/RCED-93-124, Government Printing Office, Washington D.C., 1993).

2. U.S. Nuclear Waste Technical Review Board, Report to Congress and the Secretary of Energy (Washington, D.C., March, 1993).

3. "P. Slovic, M. Layman, N. Kraus, J. Flynn, J. Chalmers, and G. Gesell, G. "Perceived Risk, Stigma, and Potential Economic Impacts of a High-Level Nuclear Waste Repository in Nevada," Risk Analysis 11, 683-696 (1991). 
4. J. A. Chalmers, Deposition in the matter of the Department of Energy application for water permit (State of Nevada, State Engineer, September 13, 1991).

5. D. MacGregor, P. Slovic, R. G. Mason, J. Detweiler, S. E. Binney, and B. Dodd, "Perceived Risks of Radioactive Waste Transport Through Oregon: Results of a Statewide Survey," Risk Analysis (in press).

6. D. Easterling and H. Kunreuther, "The Vulnerability of the Convention Industry to the Siting of a High-Level Nuclear Waste Repository." In R. E. Dunlap, M. E. Kraft, and E. A. Rosa (eds.), Public Reactions to Nuclear Waste (Durham, NC: Duke University Press, 1993, pp. 209-238).

7. J. Flynn, P. Slovic, and C. K. Mertz, "The Nevada Initiative: A Risk Communication Fiasco, " Risk Analysis, 13, 497-502 (1993).

8. M. Fishbein and I. Ajzen, "Predicting and Understanding Consumer Behavior: AttitudeBehavior Correspondence." In I. Ajzen and M. Fishbein (eds.), Understanding Attitudes and Predicting Social Behavior (Englewood Cliffs, NJ: Printice-Hall, 1980).

9. A. Baum, R.J. Gatchel, and M.A. Schaeffer, "Emotional, Behavioral and Physiological Effects of Chronic Stress at Three Mile Island," Journal of Consulting and Clinical Psychology, 51, 565-572 (1983).

10. "Hanford Site Name Change Suggested," Las Vegas Review Journal, p. 15A (October 4, 1990).

11. Wald, M. L., "Energy Department to Pay $\$ 73$ Million To Settle Uranium Case in Ohio," New York Times, p. 1 (July 1, 1989).

12. R.E. Kasperson et al., "The Social Amplification of Risk: A Conceptual Framework," Risk Analysis, 8, 177-187 (1988). 
13. J. S. Petterson, "Perception vs. Reality of Radiological Impact: The Goiania Model," Nuclear News 31, 84-90 (1988).

14. Edelstein, M. R., "Towards a Theory of Environmental Stigma." In J. Henry and D. Henning (eds.), Public Environments (Ottawa, Canada: Environmental Design Research Association, 1987, pp. 21-25).

15. J. D. Rosen, "Much Ado about Alar," Issues in Science and Technology, 7(1), 85-90 (Fall, 1990).

16. M. L. Mitchell, "The Impact of External Parties on Brand-Name Capital: The 1982 Tylenol Poisonings and Subsequent Cases, "Economic Inquiry 27, 601-618 (October 1989).

17. U.S. Department of Energy, Section 175 Report: Secretary of Energy's Report to the Congress Pursuant to Section 175 of the Nuclear Waste Policy Act as Amended (Washington, D.C., December, 1988).

18. J. Flynn, R. Kasperson, H. Kunreuther, and P. Slovic, "Time to Rethink Nuclear Waste Storage," Issues in Science and Technology 8(4), 42-48 (1992).

19. D. H. Leroy and T. S. Nadler, "Negotiate Way Out of Siting Dilemmas, "Forum for Applied Research and Public Policy 8(1), 102-107 (1993).

20. H. Kunreuther, K. Fitzgerald, and T. D. Aarts, "Siting Noxious Facilities: A Test of the Facility Siting Credo," Risk Analysis 13, 301-318.

21. R. Fort, R. Rosenman, and W. Budd, "Perception Costs and NIMBY," Journal of Environmental Management 38, 185-200 (1993). 